\title{
Events of Heavy Rainfall and Strong Winds in Sao Paulo State, Brazil
}

\author{
Sergio H. Franchito ${ }^{1}$, V. Brahmananda Rao ${ }^{1}$, Manoel A. Gan ${ }^{1}$, Clovis M. E. Santo ${ }^{1}$, Jorge C. Conforte ${ }^{1}$, Jose L. \\ Stech $^{1}$, Arley F. Souza ${ }^{1} \&$ Jose Francisco Resende da Silva ${ }^{2}$ \\ ${ }^{1}$ Centro de Previsão de Tempo e Estudos Climáticos (CPTEC), Instituto Nacional de Pesquisas Espaciais (INPE), \\ Brazil \\ ${ }^{2}$ Elektro Distribuidora de Energia Ltda, Brazil \\ Correspondence: Sergio H. Franchito, Centro de Previsão de Tempo e Estudos Climáticos, CPTEC, Instituto \\ Nacional de Pesquisas Espaciais, INPE, C.P. 515, 12245-970, São José dos Campos, SP, Brazil. E-mail: \\ sergio.franchito@cptec.inpe.br
}

Received: August 2, 2015

Accepted: August 20, $2015 \quad$ Online Published: November 26, 2015

doi:10.5539/jgg.v7n4p7

URL: http://dx.doi.org/10.5539/jgg.v7n4p7

This research was financed by Elektro Ltda company of electric energy distribution (Project Elektro/Climatico).

\begin{abstract}
The relationships of strong winds and heavy rainfall in Sao Paulo State, Brazil, was investigated. Wind data from Project Elektro/Climatico collected by thirteen Platforms of Data Collection were used. The results showed that in the west sector the occurrence of strong winds was higher in the center and south areas and decreased northwards. In the central sector the occurrence of strong wind episodes was higher southwards while in the litoral it was lower due to probably the lack of wind data collected during the austral summer. In Teodoro Sampaio, Andradina, Santa Rita d'Oeste, Votuporanga (west), Rio Claro, Tatui (central) and Ubatuba (litoral) 15, $18,28,12,11,7$ and 3 extreme events occurred, respectively (maximum wind higher than $20 \mathrm{~m} \mathrm{~s}^{-1}$ together with rainfall higher than $25 \mathrm{~mm} \mathrm{day}^{-1}$ ). A case study of an episode of extreme event which occurred in Andradina on 15 October 2009 was examined. Heavy rainfall accompanied with high winds and strong divergence at $200 \mathrm{hPa}$ and ascending motion were observed in the region due to intense convection along a cold front that moved fast over Sao Paulo State.

The identification of regions with strong winds and their relation with heavy precipitation must drive electrical energy generation and distribution what is important nowadays. So, the main importance of this research is its applicability to the energy sector.
\end{abstract}

Keywords: strong winds, heavy rainfall, Sao Paulo State

\section{Introduction}

The southeastern region of Brazil (SEB) is the most populous and plays an important role in the economy of the country, being characterized by high industrial activity, agricultural productivity and hydroelectric generation. Episodes of rainstorms with strong winds in this region may have drastic economical and social impacts. Some studies have been made to broach the happening of severe weather in SEB (da Silva \& Satyamurty (2001); Fernandez et al. (2001); Lima et al. (2010); Seluchi et al. (2011)). Situations of heavy rainfall and strong winds are very common during summer, but may also occur in the transition seasons as it happens in Itu (30 Sept 1991) (Massambani et al. (1992)) and Indaiatuba (24 May 2005) (www.apolo11.com/tornados.php?posic=dat_20050526-193053.inc) in Sao Paulo State, Brazil. According to the International Panel on Climate Change Four Assessment (IPCC AR4) the extreme events of heavy rainfall and strong winds (including floods) have been more severe and frequent. Groisman et al (2005) and Marengo et al. (2009) detected in SEB an increase in the frequency of extreme rainfall events. Then, there is a need to monitor the meteorological conditions in order to provide information for the management of the impact of adverse climate conditions not only by the civil defense but also by the companies of electric energy.

From years 2008 to 2010 a project (Project Elektro/Climatico) was developed for monitoring the wind at surface in Sao Paulo State which is the most populous and economically important state not only of the SEB, but of the entire country. The areas of study were concentrated particularly in the regions of concession of electric energy 
distribution of the Elektro Ltda. corporation (Figure 1a) since the monitoring of the wind is essential to the distribution of electricity. For this purpose, thirteen Platforms of Data Collection (PDC) (Figure 2a) were installed on posts of $10 \mathrm{~m}$ height in the regions of concession of the company to record the values of maximum wind that are transmitted via satellite at each hour to a database of the project. Also the equipment stores (in internal memory) the values of wind at each minute. The download of these data can be made according to the interest of Elektro Ltda. and inserted later in the database of the project. Thus, a unique dataset was available to Elektro Ltda., with a high density and high frequency of wind information collected in the areas of concession. The regions where the PDC were installed are given in Figure $1 \mathrm{~b}$.

a)

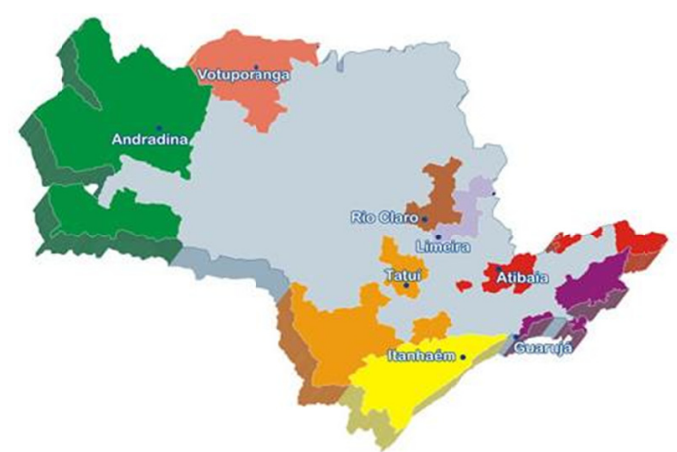

b)

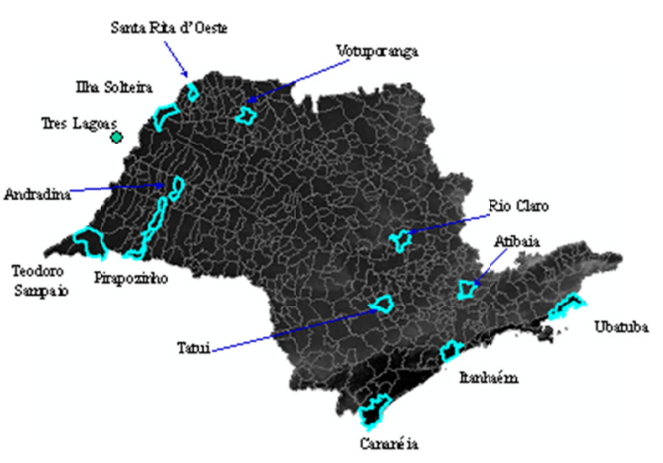

Figure 1. a) Regions of concession of Elektro Ltda, and b) Regions where the PDC were instaled

During the period of the project many episodes of strong winds were detected indicating the possibility of occurrence of rainstorm and damage for the people. In this study we show the relationships of strong winds collected in the PDCs project and heavy rainfall. A case study of strong winds is selected and associated with the occurrence of adverse climate situations which caused injury to the people.

\section{Methodoly}

The project Elektro/Climatico was financed by the Elektro Ltda. company of electric energy. The objective of the project was to monitor the wind conditions in the areas of concession of the company (Figures 1a). For this purpose thirteen PDC (Figure 2a) were installed on posts of $10 \mathrm{~m}$ height in the regions of concession of Elektro. In the west sector the cities chosen are Teodoro Sampaio (located southwards), Andradina (in the center), Santa Rita d'Oeste (northwest) and Votuporanga (north). In the central sector the cities chosen are Tatuí (located slightly to south) and Rio Claro (slightly to north) and in the litoral Ubatuba city is chosen (Figure 1b). Figure 2b illustrates the instalation of the post in Rio Claro (central sector). The PDC consists in an electronic system of data collection and storage and transmission of data via satellite. The equipment stores (in internal memory) the values of the wind at each minute for a later download according to the interest of Elektro. The firmware of the system of data collection determines the maximum wind velocity and its direction at each hour which is transmitted via satellite to a data base of the project (http://www.dpi.inpe.br/sima/vento). 
a)

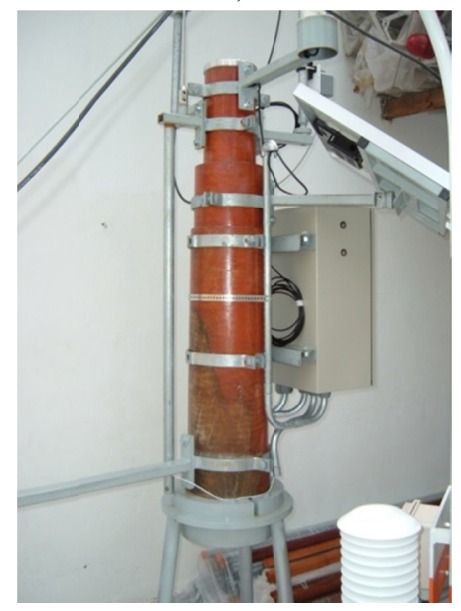

b)

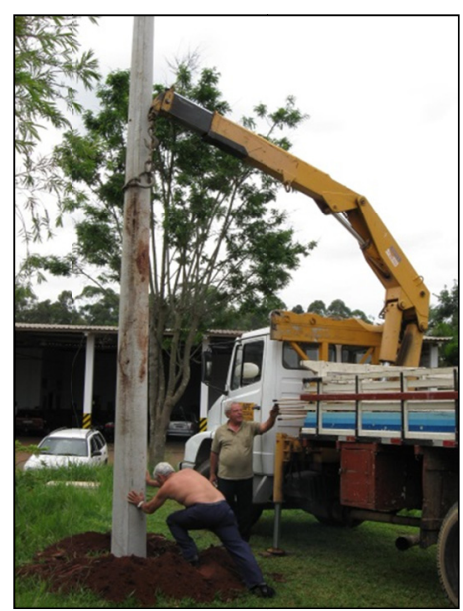

Figure 2. a) Platform of Data Collection installed on a post of $10 \mathrm{~m}$ height in the regions of concession of Elektro Ltda: west sector: Teodoro Sampaio, Pirapozinho, Andradina, Ilha Solteira, Santa Rita d'Oeste, Votuporanga, Três Lagoas; central sector: Tatuí and Rio Claro; and litoral: Ubatuba and Cananéia, b) Installation of the post in Rio Claro (central sector)

In the present work the statistics of episodes of strong winds are studied assuming as strong winds values of wind velocity higher than $15 \mathrm{~m} \mathrm{~s}^{-1}$ (approximately $54 \mathrm{~km} \mathrm{~h}^{-1}$ ). Magnitude of winds less than $15 \mathrm{~m} \mathrm{~s}^{-1}$ are weak winds which frequently are not capable to cause meteorological adverse conditions.

In order to study the relationships between episodes of strong winds and heavy rainfall winds higher than $20 \mathrm{~m}$ $\mathrm{s}^{-1}$ (approximately $72 \mathrm{~km} \mathrm{~h}^{-1}$ ) together with rainfall higher than $25 \mathrm{~mm}$ day $^{-1}$ are assumed as extreme events which may be catastrophic causing harmful consequences for the distribution of electric energy and people. Wind velocities above $20 \mathrm{~m} \mathrm{~s} \mathrm{~s}^{-1}$, classified as strong wind in the Beaufort scale (https://en.wikipedia.org/wiki/Beaufort_scale), may cause damages on tree branches and small temporally signs and barricades blow over. Thus a $20 \mathrm{~m} \mathrm{~s}^{-1}$ wind velocity may be a fair threshold for the study area since, historically, no wind velocity greater than $30 \mathrm{~m} \mathrm{~s}^{-1}$ has been observed. $85 \%$ of the daily precipitation over the considered region was lower than $25 \mathrm{~mm}$, which was set as the threshold for heavy precipitation.

\section{The divergence is calculated using GRADS}

\section{Statistics of Episodes of Strong Winds}

In this section the statistics of strong wind episodes are presented in the three sectors (west, central and litoral) of the regions of concession of Elektro Ltda In the cities of the west and central sectors the records of winds were continuous since the installation of the PDC. The statistics of episodes of strong winds to be presented take into account the period from April 2009 to May 2010 (sector west) and from February 2009 to May 2010 (sector central). In the case of Ubatuba the records of winds were continuous since the installation of the PDC until October 2009. The data collection was interrupted in the PDC because of a electric discharge that damaged the equipment. When this problem was solved the collection of data was continuous again. Then, the statistics of the occurrence of strong winds to be presented include the period from February 2009 to October 2009 and from February 2010 to May 2010. It was assumed as strong winds the values of wind velocity higher than $15 \mathrm{~m} \mathrm{~s}^{-1}$ (approximately $54 \mathrm{~km}$ day-1).

Table 1 shows the number of episodes of strong wind in the periods considered in each region. Statistics of the occurrence of strong winds are presented in Figure 3 (west sector) and Figure 4 (central and litoral sectors). In Teodoro Sampaio, Andradina and Santa Rita d'Oeste occurred 449, 897 and 648 episodes of strong winds, respectively. The prevailing direction of winds was from southeast. In the case of Santa Rita d'Oeste the dominant winds were from southeast and northeast. In Votuporanga (located northwards) 394 episodes of strong winds occurred, with prevailing direction from northeast. Then, in the west sector the occurrence of strong winds was higher in the center and south areas (with predominant direction from southeast) and decreased northwards (with predominant direction from northeast). In the central sector the occurrence of episodes of strong winds was higher southwards (Tatui - 213 episodes), with prevailing direction from southeast. In Rio Claro (located 
northwards in this sector) 176 episodes occurred with a predominant direction from northeast. In the litoral (Ubatuba) the occurrence of events of strong winds was lower than in the other sectors (5 episodes). This may be due to the fact that there are no records of the months of November, December and January which correspond to rainy periods.

Table 1. Number of episodes of strong winds in the cities of the regions west, central and litoral in the area of concession of Elektro Ltda

\begin{tabular}{ccccccc}
\hline Teodoro Sampaio & Andradina & Santa Rita d'Oeste & Votuporanga & Tatuí & Rio Claro & Ubatuba \\
\hline 449 & 897 & 648 & 394 & 213 & 176 & 5 \\
\hline
\end{tabular}
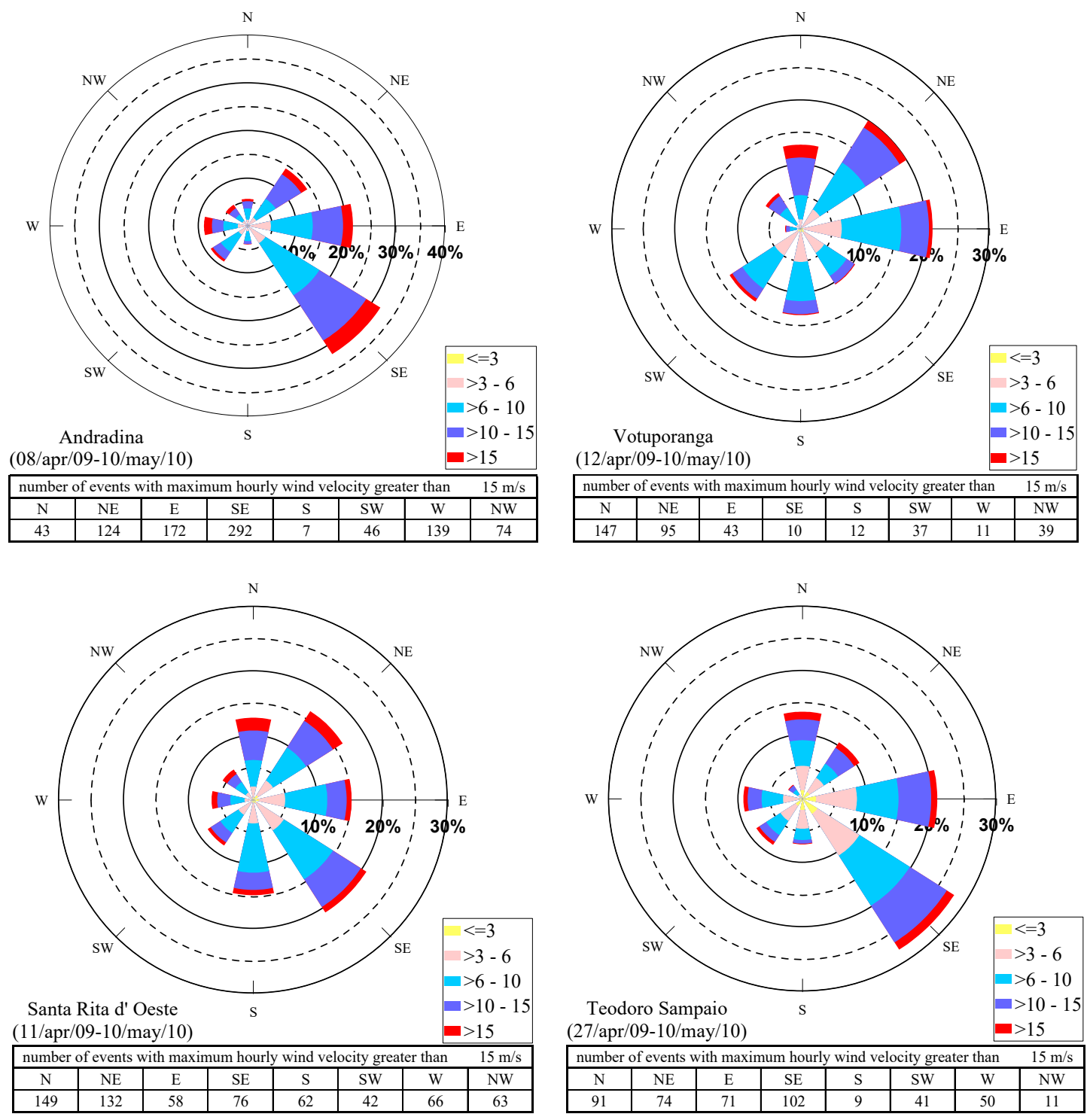

Figure 3. Distribution of hourly winds in the PDC located in the west sector: Andradina (08/apr/09-10/may/10),

Votuporanga (12/apr/09-10/may/10), Santa Rita d' Oeste (11/apr/09-10/may/10) and Teodoro Sampaio

(27/apr/09-10/may/10). The tables in the bottom of the figures shows the number of episodes of strong winds occurred during the period of analysis 

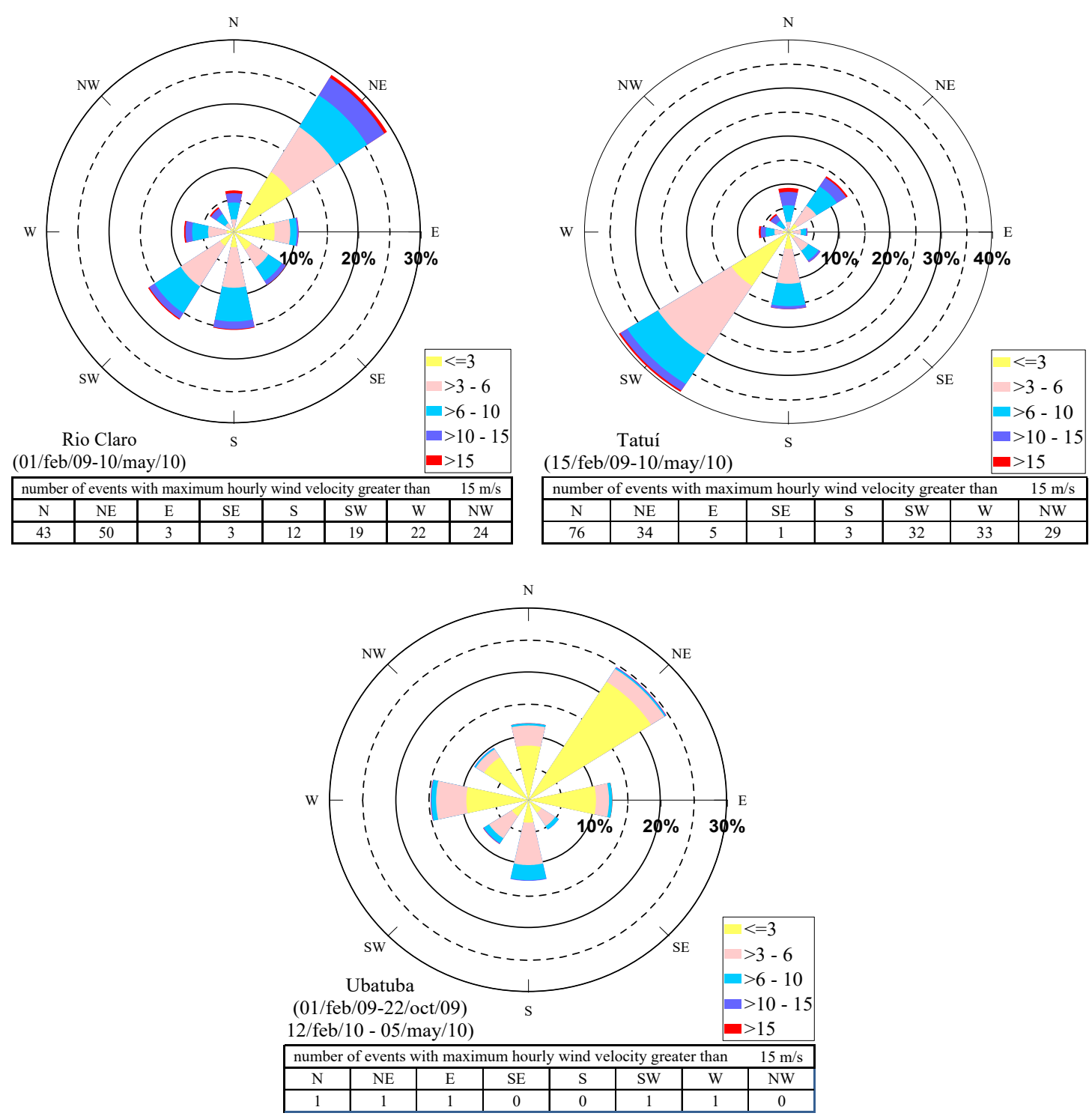

Figure 4. The same as in Figure 3, but for the central sector (Tatui: 15/feb/09-10/may/10 and Rio Claro: 01/feb/09-10/may/10) and litoral (Ubatuba: 01/feb/09-22/oct/09; 12/feb/10-05/may/10)

\section{Relationships between Episodes of Strong Winds and Heavy Rainfall}

In this section the relationships between strong winds and heavy precipitation is investigated. For this purpose the data series from June 2009 to May 2010 is considered. The data of maximum wind are obtained from the dataset of the project (www.dpi.inpe.br/sima/vento) and the data of rainfall is obtained from Instituto Agronomico de Campinas (IAC, www.iac.sp.gov.br). Winds higher than $20 \mathrm{~m} \mathrm{~s}^{-1}$ (approximately $72 \mathrm{~km} \mathrm{~h}^{-1}$ ) together with rainfall higher than $25 \mathrm{~mm} \mathrm{day}^{-1}$ are assumed as extreme events which may be catastrophic and cause damage for the distribution of electric power and put lives at risk. The cities in the three sectors of the areas of concession of Elektro Ltda. chosen for this analysis are the same that in section 2. Figure 5 shows the distribution of maximum wind and the rainfall for the west sector while Figure 6 presents it for the central and litoral sectors. As can be seen, there were periods when strong winds correspond to approximately peaks of rainfall. However, there were some small number of periods that although the winds were strong the amount of rainfall was low and vice-versa. 

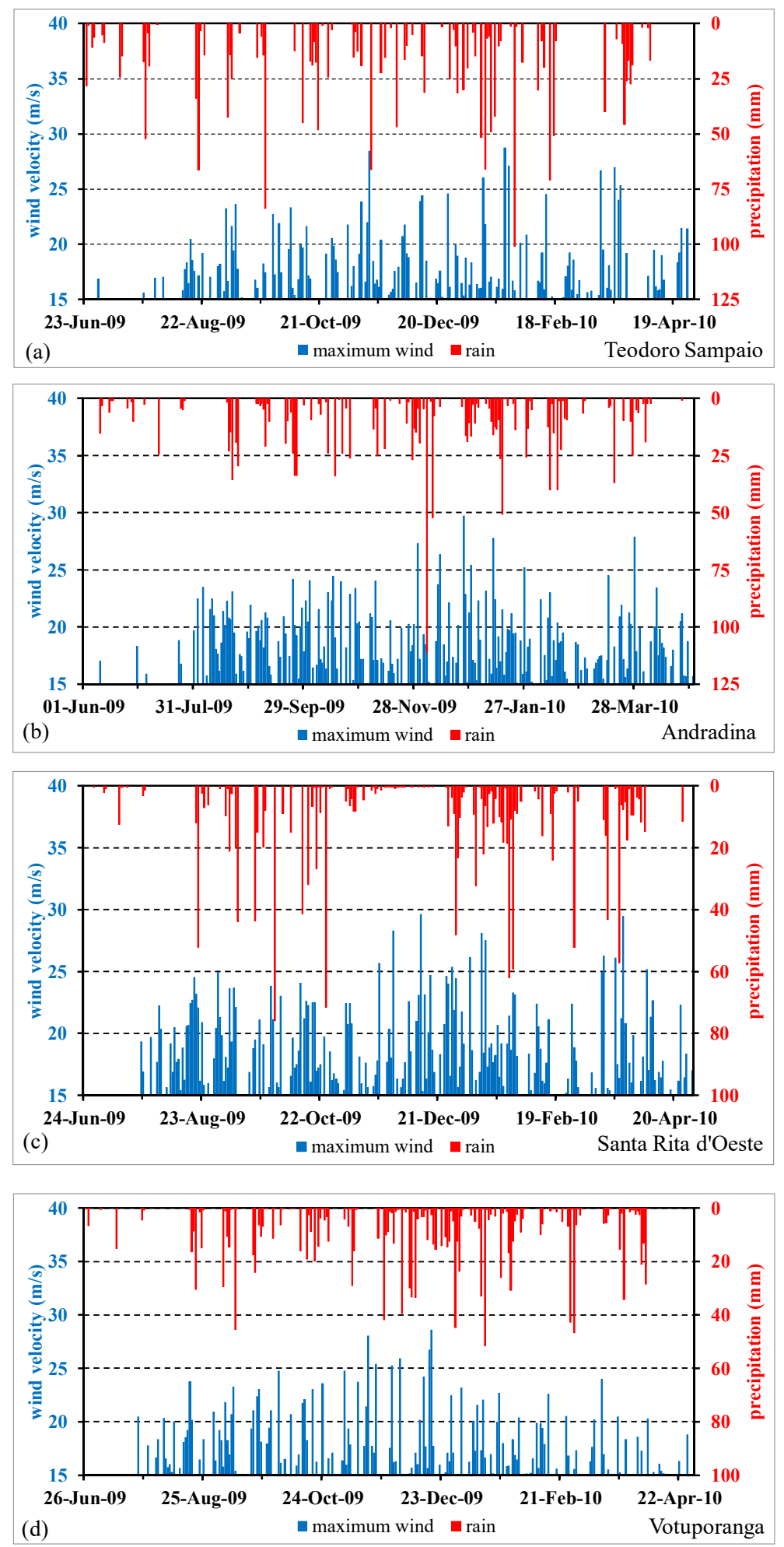

Figure 5. Distribution of maximum wind and the rainfall for the west sector of the region of concession of Elektro Ltda.: a) Teodoron Sampaio (27/apr/09-10/may/10), b) Andradina (08/apr/09-10/may/10), c) Santa Rita d'Oeste (11/apr/09-10/may/10) and d) Votuporanga (12/apr/09-10/may/10) 

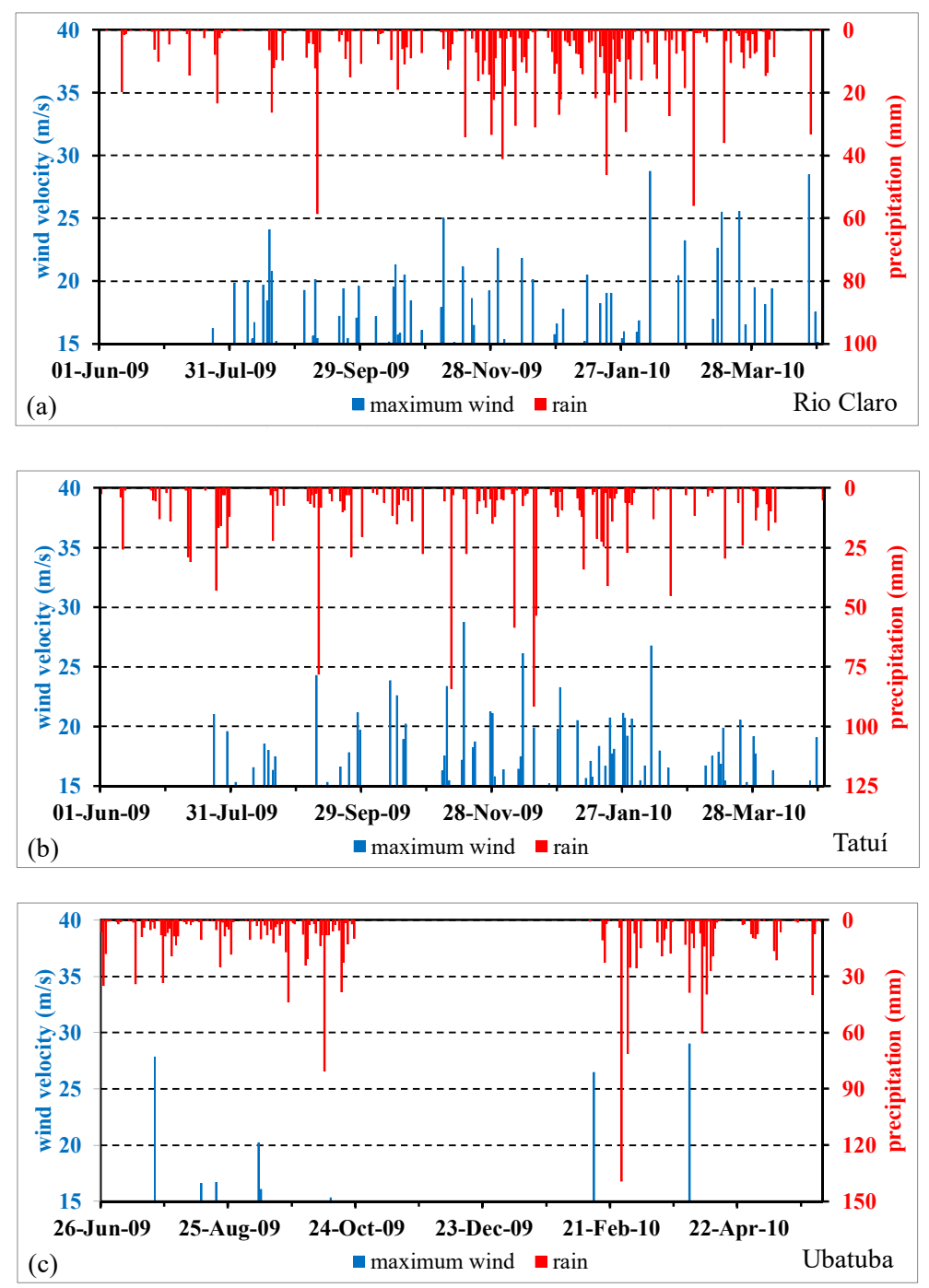

Figure 6. The same as Figure 5, but for the central sector: a) Rio Claro (01/feb/09-10/may/10), b) Tatui (15/feb/09-10/may/10), and the litoral sector: c) Ubatuba (01/feb/09-22/oct/09 and 12/feb/10-05/may/10)

Thus, in order to examine the association of strong winds and the occurrence of rainfall Figure 7 and 8 are prepared. These figures show the distribution of the maximum hourly average (left column) and daily absolute maximum wind (right column) as function of rainfall interval for the west, central and litoral sectors. As can be seen in Figure 7, in the part southwards of west sector (Teodoro Sampaio and Andradina) most of the absolute maximum winds were associated with rainfall between 10-20 mm day ${ }^{-1}$ and 20-30 mm day ${ }^{-1}$. It is also showed in this figure that some maximum wind events are associated with rainfall between $40-50 \mathrm{~mm}^{-1}$ day $^{-1}$ and 50-75 mm day $^{-1}$. In the part northwards (Santa Rita d'Oeste and Votuporanga) the higher concentration of maximum wind was associated with rainfall $5-10 \mathrm{~mm}$ day $^{-1}$ and $10-20 \mathrm{~mm} \mathrm{day}^{-1}$ and intense precipitation (more than $30 \mathrm{~mm}$ day $^{-1}$ ) in general is not associated with intense winds. In the central sector most of the maximum winds corresponded to rainfall 5-10 mm day ${ }^{-1}$ and 10-20 mm day ${ }^{-1}$ while in the litoral (Ubatuba) it was associated with rainfall $30-40 \mathrm{~mm}$ day $^{-1}$. The strongest maximum winds occurred in the west sector, followed by central and litoral sectors. 

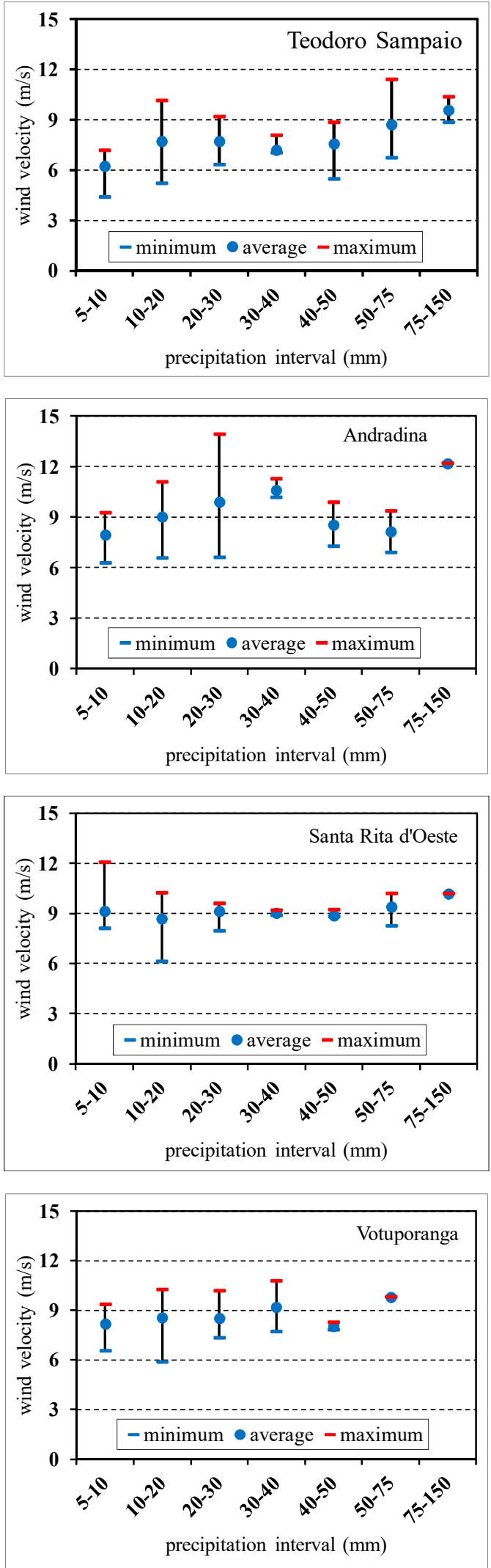
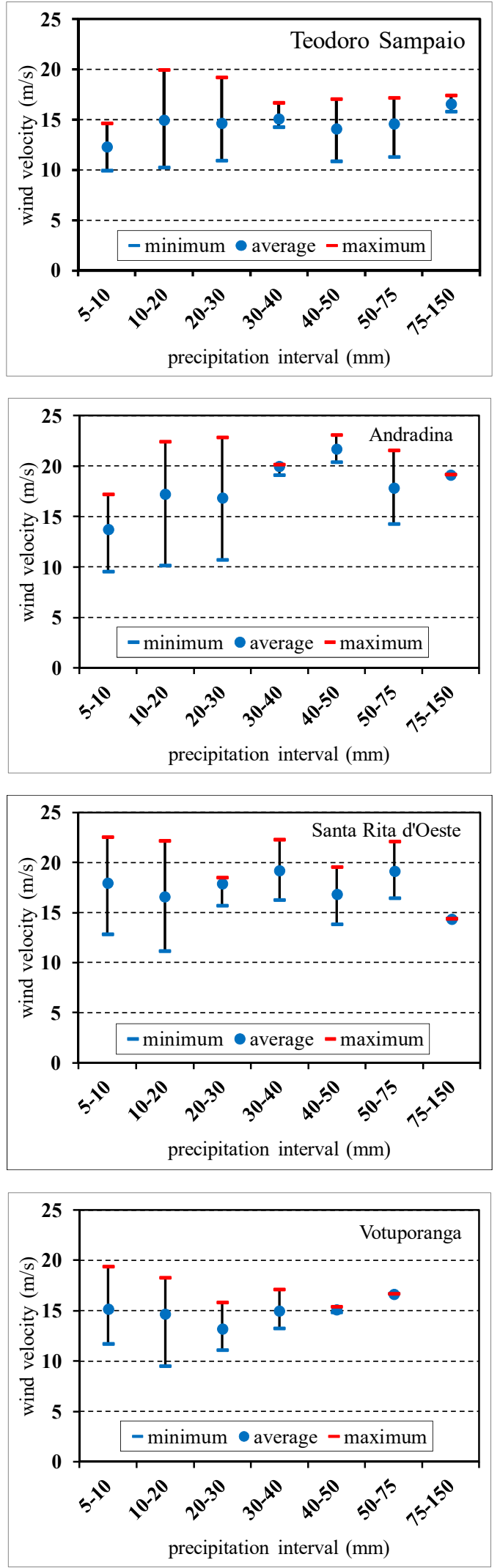

Figure 7. Distribution of the maximum hourly average (left column) and daily absolute maximum wind (right column) as function of rainfall interval for the west sector: a) Teodoro Sampaio, b) Andradina, c) Santa Rita

d'Oeste, and d) Votuporanga. The bars around the values of mean maximum wind represent a interval that includes $80 \%$ of the values of maximum wind. The data of maximum wind are obtained from the dataset of the present project and data of rainfall are obtained from IAC (www.iac.sp.gov.br) 

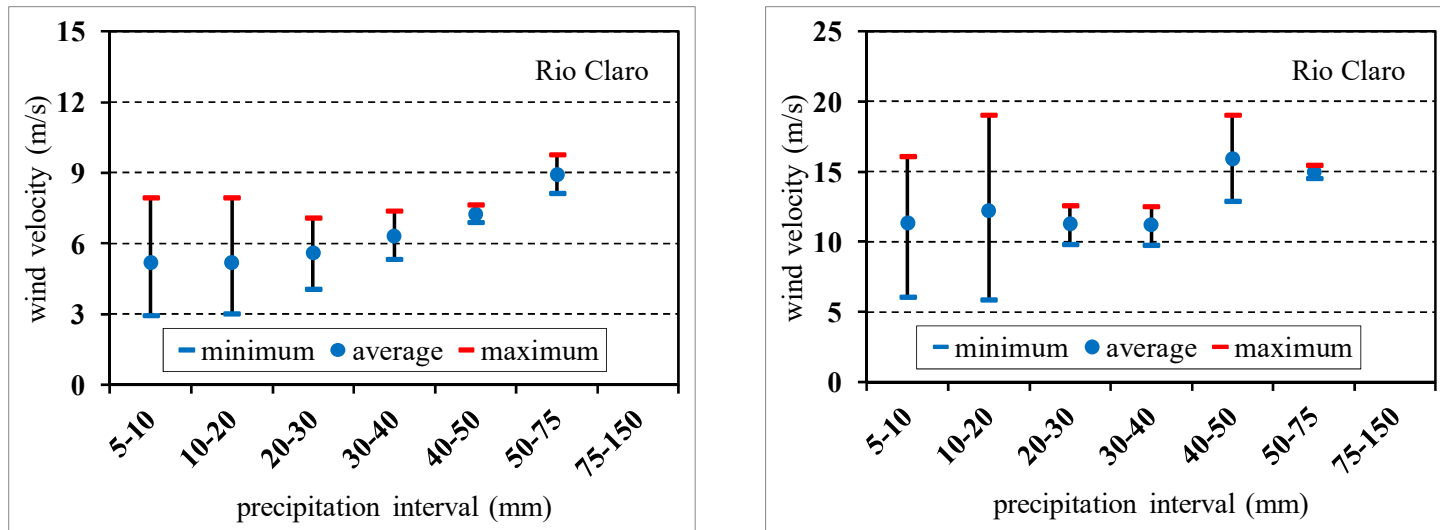

precipitation interval $(\mathrm{mm})$
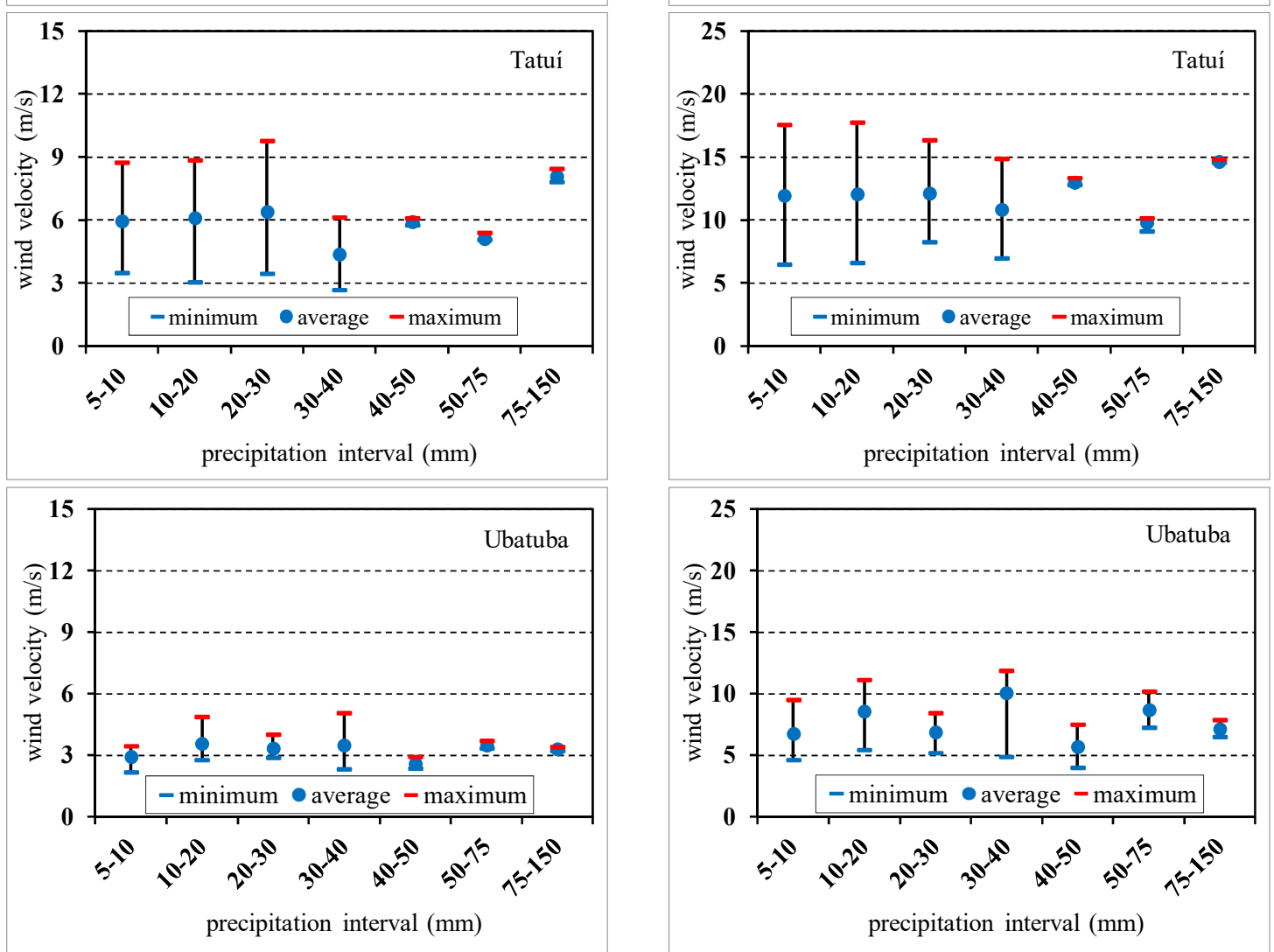

Figure 8. The same as in Figure 7, but for the central: a) Rio Claro (01/feb/09-10/may/10), b) Tatui (15/feb/09-10/may/10), and litoral sectors: c) Ubatuba (01/feb/09-22/oct/09 and 12/feb/10-05/may/10)

Tables 2-8 show the dates of extreme events in the cities of the three sectors chosen in section 2 . In these dates it was considered that the rainfall and the maximum wind occurred in the former day and in the day earlier. On these intervals of three days it happened at least an occurrence of maximum wind higher than $20 \mathrm{~m} \mathrm{~s}^{-1}$ and

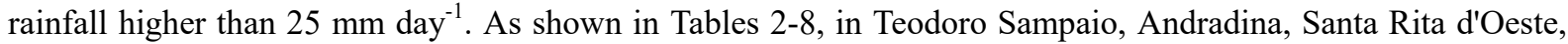
Votuporanga, Rio Claro, Tatui and Ubatuba occurred 15, 18, 28, 12, 11, 7 and 3 extreme events, respectively, that are capable of causing damage to distribution of electricity and the people. In the next section a case study of extreme event is chosen to illustrate the impact of meteorological adverse conditions in the regions of concession of Elektro Ltda. 
Table 2. Occurrence of extreme events in Teodoro Sampaio (west sector). The dates consider the rainfall (mm) and the maximum wind $\left(\mathrm{m} \mathrm{s}^{-1}\right)$ occurred in the former day and in the day earlier. In these intervals of three days it happens at least an occurrence of maximum wind higher than $20 \mathrm{~m} \mathrm{~s}^{-1}$ and rainfall higher than $25 \mathrm{~mm}$ day $^{-1}$

\begin{tabular}{crrrrrr}
\hline date & wind $(\mathrm{m} / \mathrm{s})$ & rain $(\mathrm{mm})$ & & date & wind $(\mathrm{m} / \mathrm{s})$ & rain $(\mathrm{mm})$ \\
\hline 02-Sep-09 & 23.2 & 0.0 & & 11-Jan-10 & 16.0 & 51.8 \\
04-Sep-09 & 16.6 & 42.7 & & 12-Jan-10 & 26.0 & 0.0 \\
05-Sep-09 & 11.2 & 14.2 & & 13-Jan-10 & 21.8 & 66.0 \\
13-Oct-09 & 11.2 & 0.0 & & 14-Jan-10 & 13.7 & 6.8 \\
15-Nov-09 & 28.5 & 0.0 & & 14-Feb-10 & 14.0 & 0.0 \\
16-Nov-09 & 10.2 & 66.3 & & 14-Mar-10 & 19.5 & 0.0 \\
12-Dec-09 & 24.4 & 14.8 & & 24-Mar-10 & 14.6 & 9.1 \\
13-Dec-09 & 10.5 & 31.2 & & & \\
\hline
\end{tabular}

Table 3. Occurrence of extreme events in Andradina (west sector). Legend similar to Table 2

\begin{tabular}{crrrrrr}
\hline \multicolumn{1}{c}{ date } & wind $(\mathrm{m} / \mathrm{s})$ & rain $(\mathrm{mm})$ & & date & wind $(\mathrm{m} / \mathrm{s})$ & rain $(\mathrm{mm})$ \\
\cline { 1 - 3 } \cline { 7 - 8 } 20-Aug-09 & 20.7 & 14.6 & & 14-Jan-10 & 17.0 & 26.4 \\
21-Aug-09 & 23.1 & 25.6 & & 15-Jan-10 & 21.5 & 50.8 \\
22-Aug-09 & 19.5 & 0.0 & & 16-Jan-10 & 15.8 & 0.3 \\
23-Aug-09 & 24.2 & 24.0 & & 09-Feb-10 & 20.8 & 12.5 \\
24-Sep-09 & 20.1 & 33.7 & & 10-Feb-10 & 23.0 & 40.0 \\
25-Sep-09 & 19.2 & 33.7 & & 11-Feb-10 & 15.7 & 2.3 \\
26-Sep-09 & 15.5 & 0.0 & & 13-Feb-10 & 17.1 & 0.0 \\
15-Oct-09 & 24.4 & 0.0 & & 14-Feb-10 & 20.4 & 40.0 \\
16-Oct-09 & 19.1 & 34.0 & & 15-Feb-10 & 18.6 & 1.0 \\
\hline
\end{tabular}

Table 4. Occurrence of extreme events in Santa Rita d'Oeste (west sector). Legend similar to Table 2

\begin{tabular}{crrrrrr}
\hline date & wind $(\mathrm{m} / \mathrm{s})$ & rain $(\mathrm{mm})$ & & date & wind $(\mathrm{m} / \mathrm{s})$ & rain $(\mathrm{mm})$ \\
\cline { 1 - 3 } \cline { 7 - 8 } 20-Aug-09 & 23.2 & 11.9 & & 29-Dec-09 & 21.9 & 8.9 \\
21-Aug-09 & 22.1 & 52.1 & & 30-Dec-09 & 24.4 & 48.0 \\
22-Aug-09 & 16.2 & 0.0 & & 31-Dec-09 & 15.7 & 23.1 \\
09-Sep-09 & 22.1 & 19.8 & & 25-Jan-10 & 19.2 & 18.6 \\
10-Sep-09 & 13.8 & 43.9 & & 26-Jan-10 & 21.4 & 62.0 \\
20-Sep-09 & 13.2 & 15.0 & & 27-Jan-10 & 18.7 & 10.8 \\
28-Sep-09 & 21.2 & 0.0 & & 28-Jan-10 & 23.3 & 59.2 \\
29-Sep-09 & 14.4 & 75.9 & & 29-Jan-10 & 23.1 & 7.8 \\
12-Oct-09 & 24.1 & 0.0 & & 27-Feb-10 & 22.4 & 0.0 \\
13-Oct-09 & 10.7 & 41.4 & & 28-Feb-10 & 18.9 & 52.1 \\
14-Oct-09 & 21.2 & 0.0 & & 16-Mar-10 & 13.8 & 16.0 \\
15-Oct-09 & 22.6 & 0.0 & & 22-Mar-10 & 17.5 & 0.3 \\
16-Oct-09 & 22.3 & 32.0 & & 23-Mar-10 & 16.4 & 57.2 \\
17-Oct-09 & 16.1 & 0.0 & & 24-Mar-10 & 21.2 & 6.1 \\
\hline
\end{tabular}

Table 5. Occurrence of extreme events in Votuporanga (west sector). Legend similar to Table 2

\begin{tabular}{crrrrrr}
\hline \multicolumn{1}{c}{ date } & wind $(\mathrm{m} / \mathrm{s})$ & rain $(\mathrm{mm})$ & & date & wind $(\mathrm{m} / \mathrm{s})$ & rain $(\mathrm{mm})$ \\
\cline { 1 - 2 } 20-Aug-09 & 14.3 & 8.6 & & 29-Dec-09 & 17.1 & 4.8 \\
09-Sep-09 & 23.3 & 0.0 & & 11-Jan-10 & 13.1 & 7.6 \\
10-Sep-09 & 15.4 & 45.5 & & 12-Jan-10 & 17.3 & 33.0 \\
02-Dec-09 & 25.9 & 0.3 & & 13-Jan-10 & 22.0 & 0.3 \\
03-Dec-09 & 12.6 & 39.6 & & 14-Jan-10 & 16.7 & 51.6 \\
11-Dec-09 & 16.0 & 4.1 & & 25-Feb-10 & 16.8 & 6.9 \\
\hline
\end{tabular}


Table 6. Occurrence of extreme events in Rio Claro (central sector). Legend similar to Table 2

\begin{tabular}{crrrrrr}
\hline date & wind $(\mathrm{m} / \mathrm{s})$ & rain $(\mathrm{mm})$ & & date & wind $(\mathrm{m} / \mathrm{s})$ & rain $(\mathrm{mm})$ \\
\cline { 1 - 4 } \cline { 6 - 7 } 08-Sep-09 & 20.1 & 12.2 & & 18-Dec-09 & 12.5 & 31.1 \\
09-Sep-09 & 15.4 & 58.5 & & 14-Mar-10 & 25.5 & 0.0 \\
15-Nov-09 & 21.1 & 0.0 & & 15-Mar-10 & 12.1 & 36.0 \\
16-Nov-09 & 13.6 & 34.2 & & 23-Apr-10 & 28.5 & 0.0 \\
02-Dec-09 & 10.1 & 2.5 & & 24-Apr-10 & 8.6 & 33.2 \\
17-Dec-09 & 20.1 & 0.8 & & & & \\
\hline
\end{tabular}

Table 7. Occurrence of extreme events in Tatui (central sector). Legend similar to Table 2

\begin{tabular}{crrrrrr}
\hline date & wind $(\mathrm{m} / \mathrm{s})$ & rain $(\mathrm{mm})$ & & date & wind $(\mathrm{m} / \mathrm{s})$ & rain $(\mathrm{mm})$ \\
\cline { 1 - 1 } \cline { 6 - 7 } 23-Jul-09 & 21.0 & 0.0 & & 08-Nov-09 & 15.4 & 0.0 \\
24-Jul-09 & 10.9 & 43.0 & & 20-Jan-10 & 13.3 & 41.0 \\
08-Sep-09 & 24.3 & 2.2 & & 21-Jan-10 & 20.7 & 4.0 \\
09-Sep-09 & 14.7 & 78.2 & & & & \\
\hline
\end{tabular}

Table 8. Occurrence of extreme events in Ubatuba (litoral sector). Legend similar to Table 2

\begin{tabular}{crr}
\hline date & wind $(\mathrm{m} / \mathrm{s})$ & rain $(\mathrm{mm})$ \\
\hline 29-Mar-10 & 7.4 & 0.3 \\
30-Mar-10 & 29.0 & 38.6 \\
31-Mar-10 & 6.2 & 7.1 \\
\hline
\end{tabular}

\section{Case Study}

Based on Table 3, the episode of extreme event occurred in Andradina $\left(20.89^{\circ}, 51.37^{\circ} \mathrm{W}\right)$ on 15 October 2009 was chosen as a case study. On 15 October 2009 heavy rainfall (34 mm) occurred from 13:00 h to 14:30 h (LT) in Andradina accompanied with strong winds of $24.4 \mathrm{~m} \mathrm{~s}^{-1}\left(87 \mathrm{~km} \mathrm{~h}^{-1}\right)$ which caused harmful consequences to the people. Due to the strength of winds several trees fell down in many places of the city. Some trees dropped on the conducting wires of electricity affecting the transmission and distribution of electric energy. The heavy rainfall and strong winds also had harmful consequences for the movement of vehicles. Figure 9 illustrates the damage caused by this meteorological adverse condition. In order to analyze the synoptic conditions associated to the occurrence of this case of extreme event 1 hourly gridded data from Climate Forecast System Reanalysis (CFSR) with $0.5^{\circ}$ of horizontal resolution are used. For more details see Saha et al. (2010).

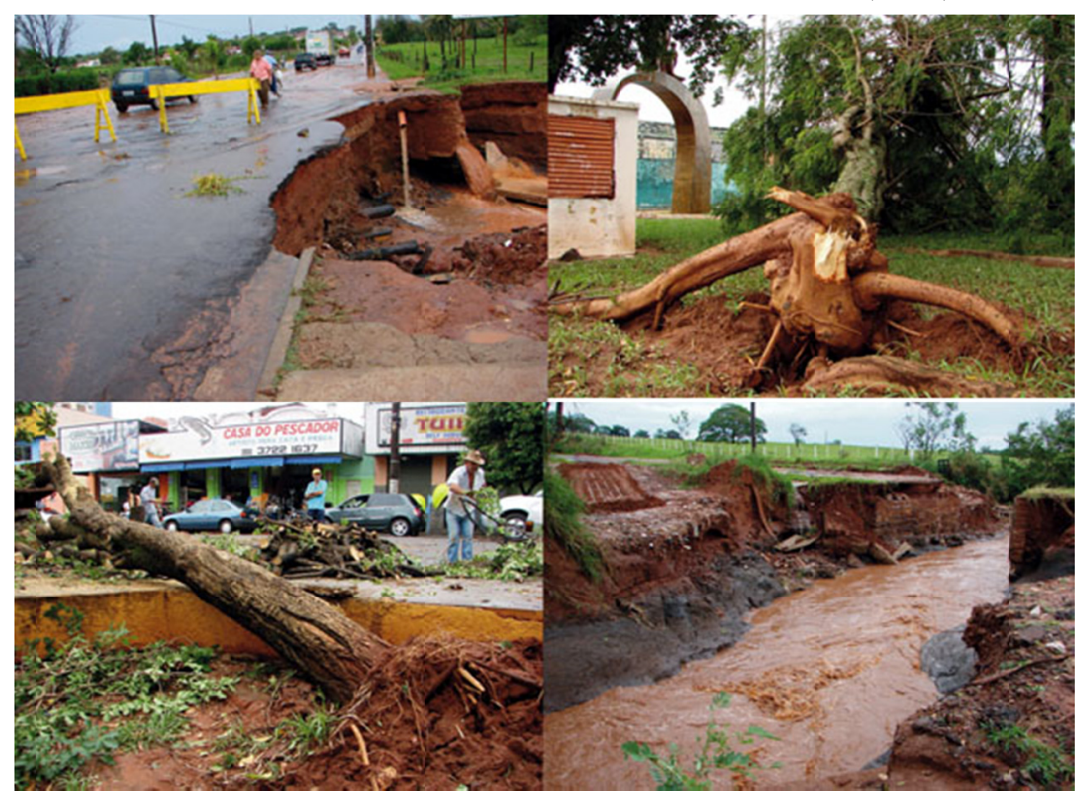

Figure 9. Damage caused by the extreme event of 15 October 2009 in Andradina (Source: journal Jornal Regional edition of 16 October 2009) 
This episode of large amounts of rainfall and high values of winds in Andradina was due to the development of convective clouds along a cold front that moved fast over Sao Paulo State as one can see a cloud band in satellite picture that extends from southeastern Mato Grosso do Sul State to Atlantic ocean (Figure 10). At 1200 UTC the cold front was over the boundary between Paraná and Sao Paulo States. As shown in Figure 11a, a region of low pressure was present in the south of Sao Paulo State at 1200 UTC. At 1800 UTC the cold front was crossing Sao Paulo State over the northern sector of the state (Figures 10b and 11c). As one can see in Figure 10a-b many mesoscale convective cloud clusters were developing along and ahead of the cold front in the morning and afternoon. Using GRADS (http://moe.met.fsu.edu/ rhart/software/plotskew.gs) a thermodynamic diagram was obtained where the CAPE (Convective Available Potential Energy, Betts (1974)) was calculated using radiosonde launched at 1200UTC in Campo Grande (Mato Grosso do Sul State). The data used are obtained from http://weather.uwyo.edu/upperair/sounding.html. The CAPE presented value higher than $1300 \mathrm{~J} \mathrm{~kg}^{-1}$ showing atmospheric instability in the region (Figure 12). Campo Grande is the place nearest to Andradina where there are soundings. Campo Grande is located approximately $300 \mathrm{~km}$ far from Andradina. Since the horizontal scope of the sounding is around $300 \mathrm{~km}$ the sounding is valid for the region of Andradina. Unfortunatelly there were no more soundings launching in Campo Grande during the day. However, taking into account that the CAPE presented high value already at 1200 UTC it can be inferred that the atmospheric instability increased during the development of the observed mesoscale convective cluster.

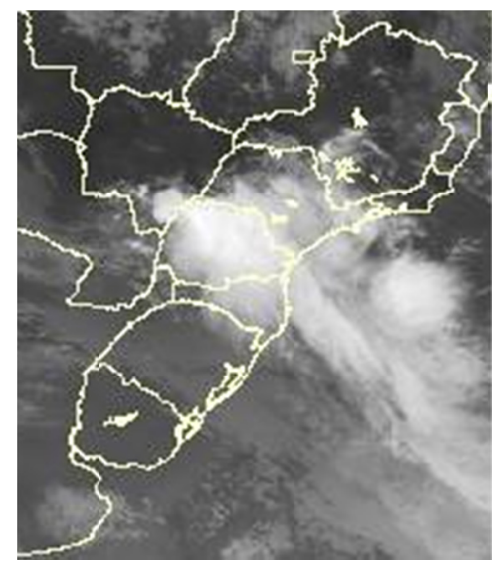

a)

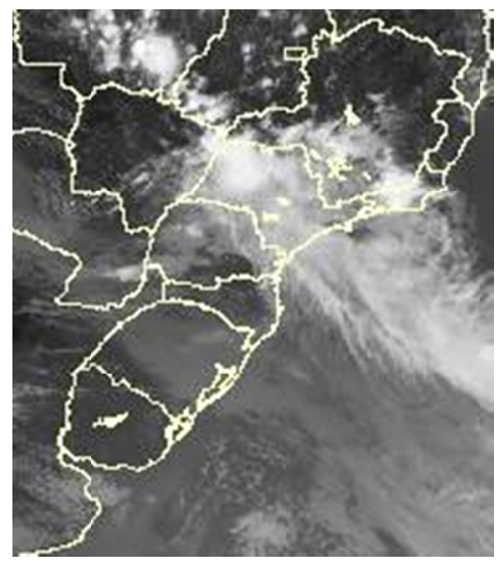

b)

Figure 10. Infrared satellite image for 15 October 209: a) 12 UTC, and b) 18 UTC

During and after the passage of the frontal system this region of low pressure extended into the interior of Sao Paulo State reaching the region of Andradina (Figures. 11b and 11c). Strong divergence at upper levels associated with difluence and intense ascending motion due to the mesoscale convective cloud cluster was observed in the region, as illustrated in Figures 13a-c and 14a-b. Figure 13b also shows the presence of strong winds at $200 \mathrm{hPa}$ (higher than $20 \mathrm{~m} \mathrm{~s}^{-1}$, i.e. higher than $72 \mathrm{~km} \mathrm{~h}^{-1}$ ). This synoptic pattern is highly favorable for the occurrence of heavy rainfall and intense vertical movement that can contribute to intensify the winds close to the surface with harmful consequences as it happened in Adradina. 


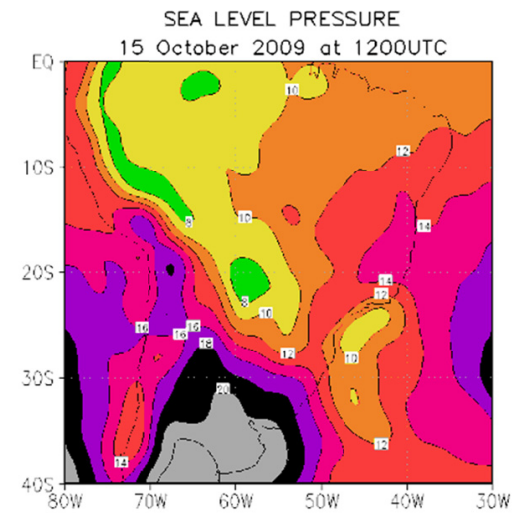

a)

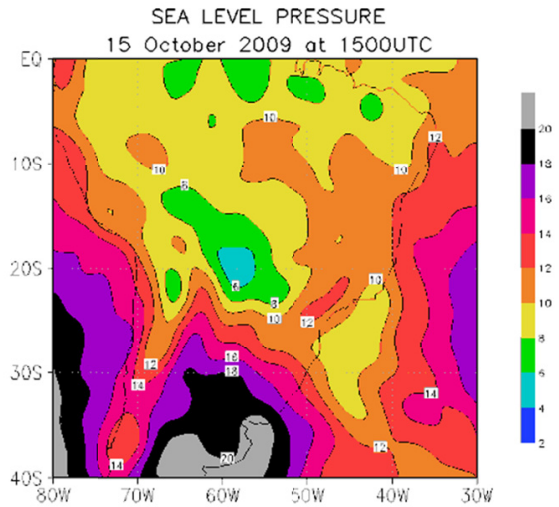

b)

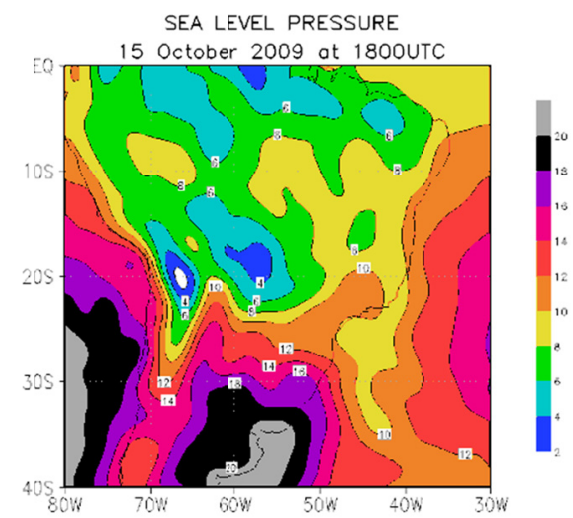

c)

Figure 11. Sea level pressure for: a) 12 UTC, b) 15 UTC, and c) 18 UTC. Units, hPa

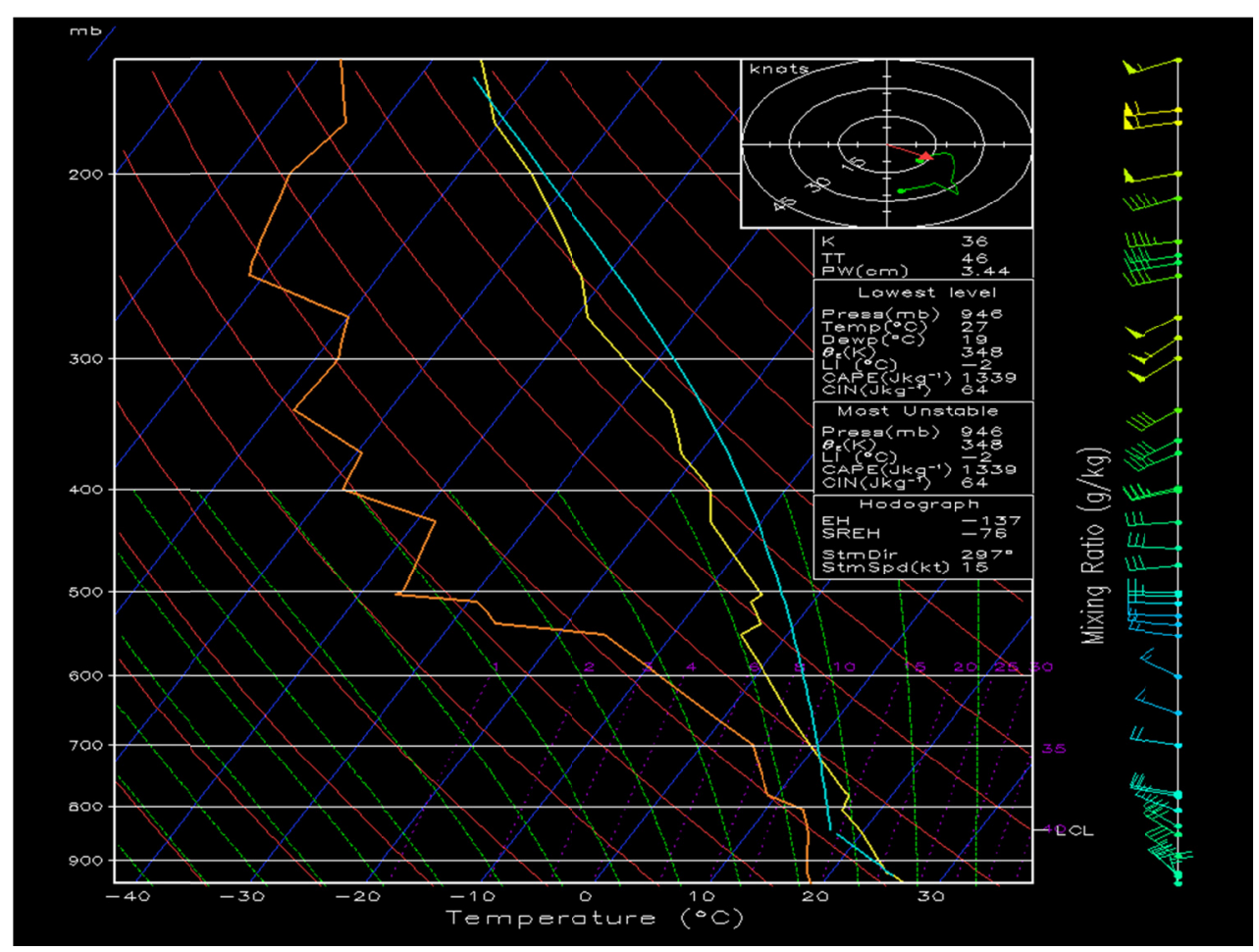

Figure 12. CAPE obtained at 1200 UTC for Campo Grande (Mato Grosso do Sul State) which is around $300 \mathrm{~km}$ far from Andradina. The orange and yellow lines refer to the temperature and dew point temperature vertical profiles. The area between the yellow line and the blue line corresponds to the CAPE 
a)

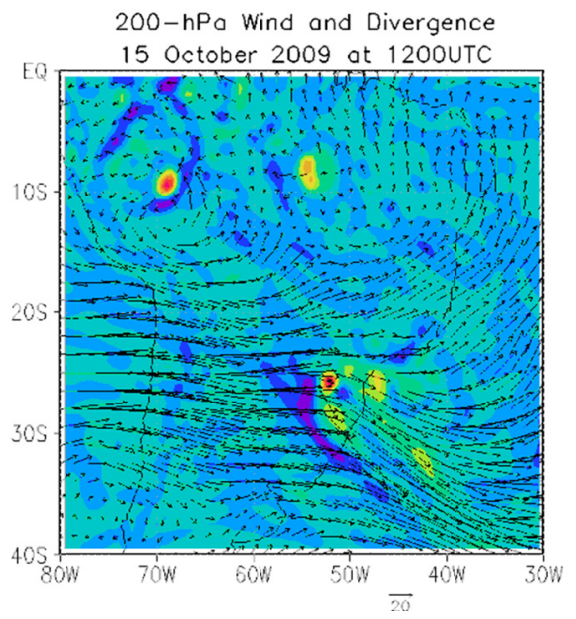

b)

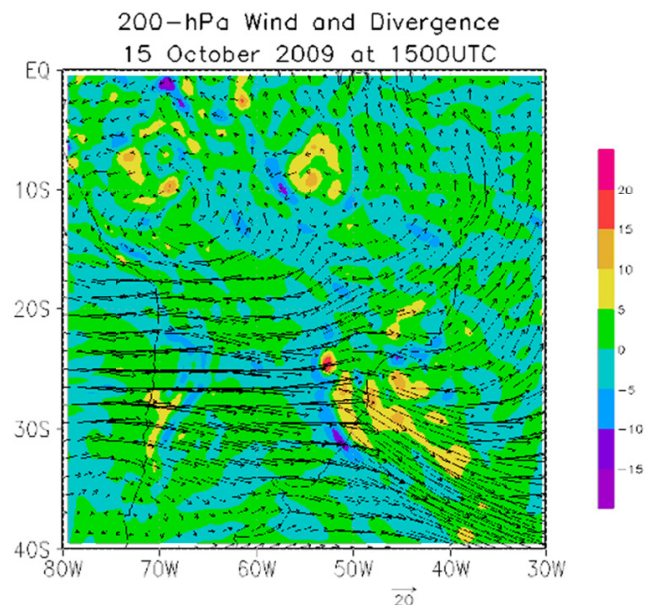

c)

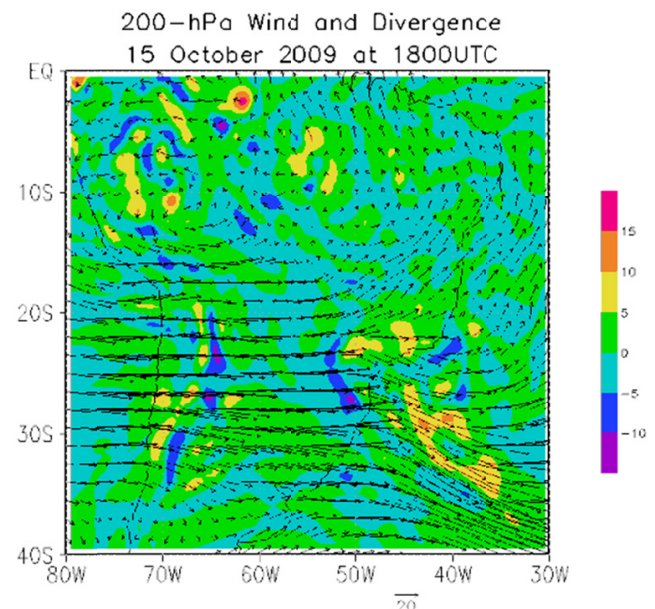

Figure 13. Divergence at $200 \mathrm{hPa}\left(\mathrm{s}^{-1}\right)$ for: a) $12 \mathrm{UTC}$, b) $15 \mathrm{UTC}$, and c) 18 UTC. Also shown are the wind vectors (m s-1).

a)

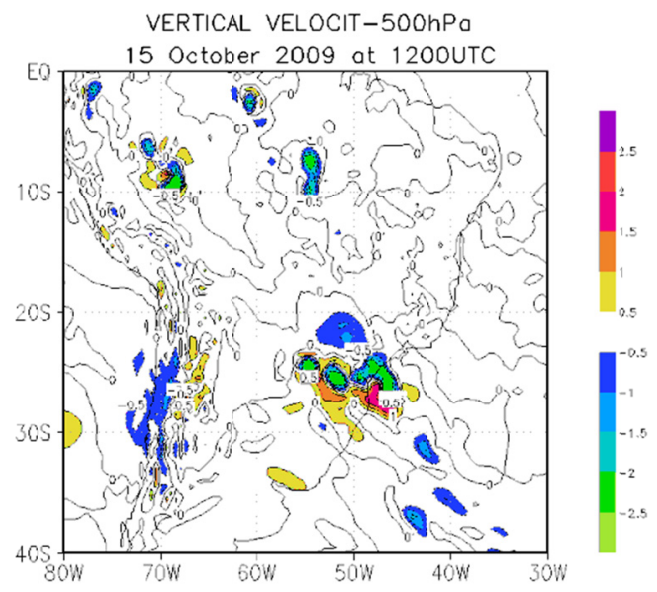

b)

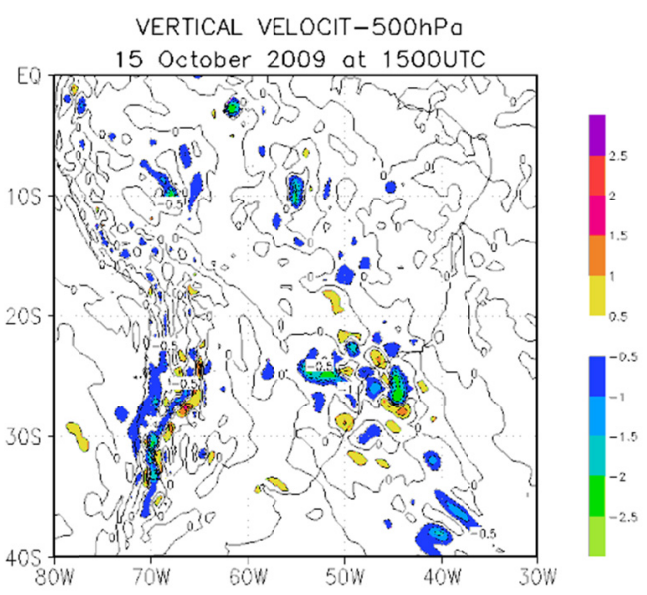

c) 


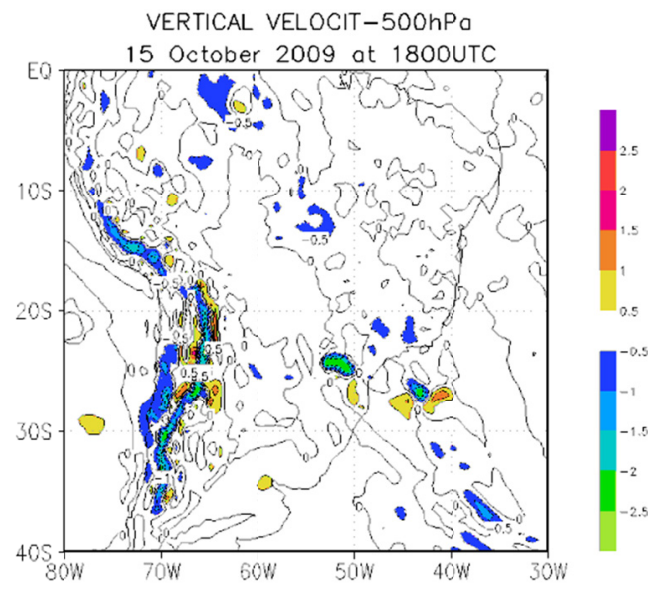

Figure 14. Vertical velocity at $500 \mathrm{hPa}$ for: a) 12 UTC, b) 15 UTC, and c) 18 UTC. Units, hPa s ${ }^{-1}$

\section{Summary and Conclusions}

In this paper the relationships of strong winds and heavy rainfall in Sao Paulo State, particularly in the region of electric energy distribution of Elektro Ltda. company, was studied. Wind data from the Project Elektro/Climatico collected by thirteen Platforms of Data Collection which were installed in the regions of concession of Elektro Ltda were used. Statistics of episodes of strong winds in the west sector of the region of concession of Elektro Ltda (period from April 2009 to May 2010) showed that in Teodoro Sampaio, Andradina and Santa Rita d'Oeste $449(6 \%), 897(11 \%)$ and $648(9 \%)$ episodes of strong winds occurred, with prevailing direction from southeast. In Votuporanga (located northwards) 394 (5\%) episodes of strong winds occurred, with prevailing direction from northeast. In the central sector the occurrence of episodes of strong winds (period from February 2009 to May 2010) was higher southwards (Tatui - 213 (2\%) episodes), with prevailing direction from southeast, while in Rio Claro (located northwards) $176(2 \%)$ episodes occurred with a predominant direction form northeast. In the litoral (period from February 2009 to October 2009 and from February 2010 to May 2010) the occurrence of events of strong winds ( 5 episodes in 4700 records) was lower than in the other sectors. This may be due to the fact that there are no records for the rainy months of November, December and January.

In the part southwards of west sector (Teodoro Sampaio and Andradina) most of the maximum winds were associated with rainfall between $10-20 \mathrm{~mm} \mathrm{day}^{-1}$ and 20-30 mm day ${ }^{-1}$. In the part northwards (Santa Rita d'Oeste and Votuporanga) the higher concentration of maximum wind was associated with rainfall of 5-10 $\mathrm{mm} \mathrm{day}^{-1}$ and $10-20 \mathrm{~mm}$ day $^{-1}$. In the central sector most of the maximum winds corresponded to rainfall 5-10 mm day ${ }^{-1}$ and $10-20 \mathrm{~mm} \mathrm{day}^{-1}$ while in the litoral (Ubatuba) it was associated with rainfall $30-40 \mathrm{~mm} \mathrm{day}^{-1}$. In Teodoro Sampaio, Andradina, Santa Rita d'Oeste, Votuporanga, Rio Claro, Tatui and Ubatuba occurred respectively 15, $18,28,12,11,7$ and 3 extreme events (maximum wind higher than $20 \mathrm{~m} \mathrm{~s}^{-1}$ and rainfall higher than $25 \mathrm{~mm}^{-1} \mathrm{y}^{-1}$ ) that are capable of untile residences and cause damage to distribution of electricity and the people.

Particurlarly, a episode of extreme event occurred in Andradina in 15 October 2009. Large amounts of rainfall $(34 \mathrm{~mm})$ occurred from 13:00 h to 14:30 h (LT) accompanied with strong winds of $24.4 \mathrm{~m} \mathrm{~s}^{-1}\left(87 \mathrm{Km} \mathrm{h}^{-1}\right)$ causing downfall of trees and affecting the transmission and distribution of electric energy provoking damage for the people. Episodes of heavy rainfall associated with strong winds close to the surface are caused by mesoscale convective cloud cluster dominated by intense convection. This episode of heavy rainfall and high values of winds in Andradina was due to the development of convective clouds along to a cold front that moved fast over Sao Paulo State. Low pressure associated with strong divergence at high levels and ascending motion were observed in the region.

The identification of regions with strong winds and their relation with heavy precipitation must drive electrical energy generation and distribution what is important nowadays. So, the main importance of this research is its applicability to the energy sector.

\section{Ackowledgements}

Thanks are due to Elektro Ltda company of electric energy distribution for financing the Project Elektro/Climatico. The wind data of the project are contained in the site: http://www.dpi.inpe.br/sima/vento. For 
a security reason the access to the data is restricted and a password is needed. To request a password an email to the manager of the project must be sent (Jose F. Resende da Silva, email: Jose.Resende@elektro.com.br).

\section{References}

Betts, A. K. (1974). Thermodynamic classification of tropical convective sounding. Mon. Wea. Rev., 108, 760-764.

Fernandez, G. B., Bulhões, E., \& da Rocha, T. B. (2011). Impacts of severe storm occurred in April 2010 along Rio de Janeiro coast. Journal of Coastal Research. Special Edition, 64, 1850-1854. Part 2.

Groisman. P. Y., Knight, R. W, Easterling, D. R., Karl. T. R., Hegerl, G. C., \& Razuvaev, V. N. (2005). Trends in intense precipitation in the climate record. Journal of Climate, 18, 1326- 1350.

Lima, K. C., Satyamurty, P., \& Fernandez, J. P. R. (2010). Large-scale atmospheric conditions associated with heavy rainfall episodes in Southeast Brazil. Theoretical and Applied Climatology. http://dx.doi.org/10.1007/s00704-009-0207-9

Marengo, J. A. (2010). Future change of climate in South America in the Late 21st Century: the CREAS Project. AGU AS Newsletter, 3(2), 5.

Massambani, O. L., Vespoli, M. V., \& Vazquez, M. A. (1992). Tornado ou microexplosão? Um diagnóstico via Radar do evento de Itú - São Paulo. In: VII Congresso Brasileiro de Meteorologia, 1992, São Paulo. Anais. São Paulo: Sociedade Brasileira de Meteorologia, 2, 763-768.

Saha, S., \& Coauthors (2010). The NCEP climate forecast system reanalysis. Bull. Amer. Meteor. Soc., 91, 1015-1057. http://dx.doi.org/10.1175/2010BAMS3001.1

Satyamurty, P., \& da Silva, M. T. (2011). Trends in the frequency of intense precipitation events in Southern and Southeastern Brazil during 1960-2004. Journal of Climate, 24, 1913-1921.

Seluchi, M. E., Chou, S. C., \& Gramani, M. (2011). A case study of a winter heavy rainfall event over the Serra do Mar in Brazil. Geofisica International, 50, 67-80.

\section{Copyrights}

Copyright for this article is retained by the author(s), with first publication rights granted to the journal.

This is an open-access article distributed under the terms and conditions of the Creative Commons Attribution license (http://creativecommons.org/licenses/by/3.0/). 